\title{
Contribution to the Study of Hot Water Scaling Phenomenon in the South of Touristic Area in Agadir City
}

\author{
M'barek Belattar'1, Said Ben-Aazza', Rabeh Aba-Aaki², Abdallah Hadfi'1, Naima Hafid1, Larbi Boukbir'1, \\ Ali Driouiche ${ }^{1}$
}

${ }^{1}$ Team "Materials and Physico-Chemistry of Water", Faculty of Science, Ibn Zohr University, Agadir, Morocco

${ }^{2}$ National Office of Electricity and Drinking water, Water branch, Regional Laboratory of Agadir, Agadir, Morocco

Email:driouiche@yahoo.fr

How to cite this paper: Belattar, M., BenAazza, S., Aba-Aaki, R., Hadfi, A., Hafid, N., Boukbir, L. and Driouiche, A. (2016) Contribution to the Study of Hot Water Scaling Phenomenon in the South of Touristic Area in Agadir City. Journal of Water Resource and Protection, 8, 1035-1043.

http://dx.doi.org/10.4236/jwarp.2016.812082

Received: September 16, 2016

Accepted: October 29, 2016

Published: November 1, 2016

Copyright (๑) 2016 by authors and Scientific Research Publishing Inc. This work is licensed under the Creative Commons Attribution International License (CC BY 4.0).

http://creativecommons.org/licenses/by/4.0/

\begin{abstract}
This work aims to study the phenomenon of scaling observed in the hot water pipelines in the southern seaside touristic installations of Agadir city. This phenomenon has led to the formation of solid deposits and adherents to the internal walls of the facilities of the hot water. This deposit is at the origin of several technical, economic and environmental problems. It causes a decrease in the lifetime of boilers and a reduction of thermal exchanges and consequently a decrease in the energy efficiency of heating systems. In the present study, the samples of scale have been carried out at different points of hot water pipelines. The characterization of different scale samples recovered was conducted by X-ray fluorescence (XRF), elemental analysis (CHNS-O), infrared spectrometry (IR), thermogravimetric analysis (TGA), differential thermal analysis (DTA), X-ray diffraction (XRD) and scanning electron microscopy (SEM). Analytical results showed that scale samples collected on different sites in touristic hot water system are mostly formed by calcium carbonate. Thermodynamic conditions in the site were favourable to the aragonite variety formation.
\end{abstract}

\section{Keywords}

Hot Water Scaling, Chemical Characterization, Calcium Carbonate, Aragonite, Agadir City

\section{Introduction}

The region of Souss Massa occupies an important place in the touristic industry of Morocco both by its natural and cultural riches as well as by its performance in the tourism sector. Agadir city remains the first destination of the Kingdom by a hotel 
capacity of 27,542 beds approximately. Touristic installations offer $16 \%$ of jobs in the region [1]. Agadir city has everything to meet its national and international visitors through offers and various products and adapted to the expectations of the customer. For this, it is imperative to make efforts to protect this sector at all levels: human resources, environment, etc.

Agadir city is served with water from groundwater sources. Wells and boreholes produce on average $250 \mathrm{l} / \mathrm{s}$ and superficial (stations for the treatment of Sidi Boushab $300 \mathrm{l} / \mathrm{s}$ and that of Tamri $700 \mathrm{l} / \mathrm{s}$ supplied respectively by the waters of the Dams Abdelmoumen and Moulay Abdellah. The hotel sector which has consumed $2265.103 \mathrm{~m}^{3}$ of water in 2014 [2] faces some problems relating to clogging of hot water pipelines due to the scaling phenomenon.

The present work has for object the identification and characterization of deposits of scale formed in hot water pipelines in the south of the touristic area of Agadir. The samples of scale have been carried out at different points. Well distributed according to the standardized methods. Several analytical techniques were used: elemental analysis CHNS-O, XRF, IR, DTA, TGA, XRD and SEM.

\section{Materials and Methods}

\subsection{Site of the Study}

Agadir city is located on the shore of the Atlantic Ocean near the foot of the western High Atlas Mountains. The collection of the Scale has been made at the level of different installations of hot water in the southern seaside touristic establishments of Agadir located at coordinates: $(30.39,-9.59)$ (Figure 1). These samples are the same kind and have the same structure. We give below the results for a deposit collected in a hot water pipeline of a tourist unit.

\subsection{Methods of Analysis}

X-Ray Fluorescence (XRF) analyses are performed on a PAN Analytical Axios. The applied voltage is $60 \mathrm{kV}$ with a current of $125 \mathrm{~mA}$ and Power $4.10^{3} \mathrm{~W}$.

Infrared spectroscopy (IR) analysis is carried out with Bruker FTIR-ATR vertex model 70 , with a resolution of $4 \mathrm{~cm}^{-1}$ in 16 scans to collect the data in an interval ranging from $4.10^{2}$ to $4.10^{3} \mathrm{~cm}^{-1}$. The samples are placed directly on the ATR crystal (Diamond of reflection). The mode used is the "total reflectance attenuated" (ATR).

$\mathrm{X}$-ray diffraction analysis was done using the appliance PAN Analytical using a diffractometer type X-Pert-Pro with an anode material of copper and a monochromator of $\mathrm{Cu}-\mathrm{K} \alpha$ radiation $(\lambda=1.5406 \AA$ ). The applied voltage is $45 \mathrm{kV}$ with a current of $40 \mathrm{~mA}$ at $25^{\circ} \mathrm{C}$. The sample morphologies are directly examined by scanning electron microscopy (SEM) using a FEG Zeiss Supra running at an accelerating voltage of $3 \mathrm{kV}$ to limit load on the sample. The thermogravimetric analysis (TGA) and differential thermal analysis (DTA) were carried out on a thermal analyser (DTG-60), under air from $0^{\circ} \mathrm{C}$ to $1100^{\circ} \mathrm{C}$ to heating rate of $10^{\circ} \mathrm{C} / \mathrm{min}$. The Elementary Analysis CHNS/O is carried out with 2000 Flash EA 1112, thermo Fisher Scientific. Software used: EAGER 300. 


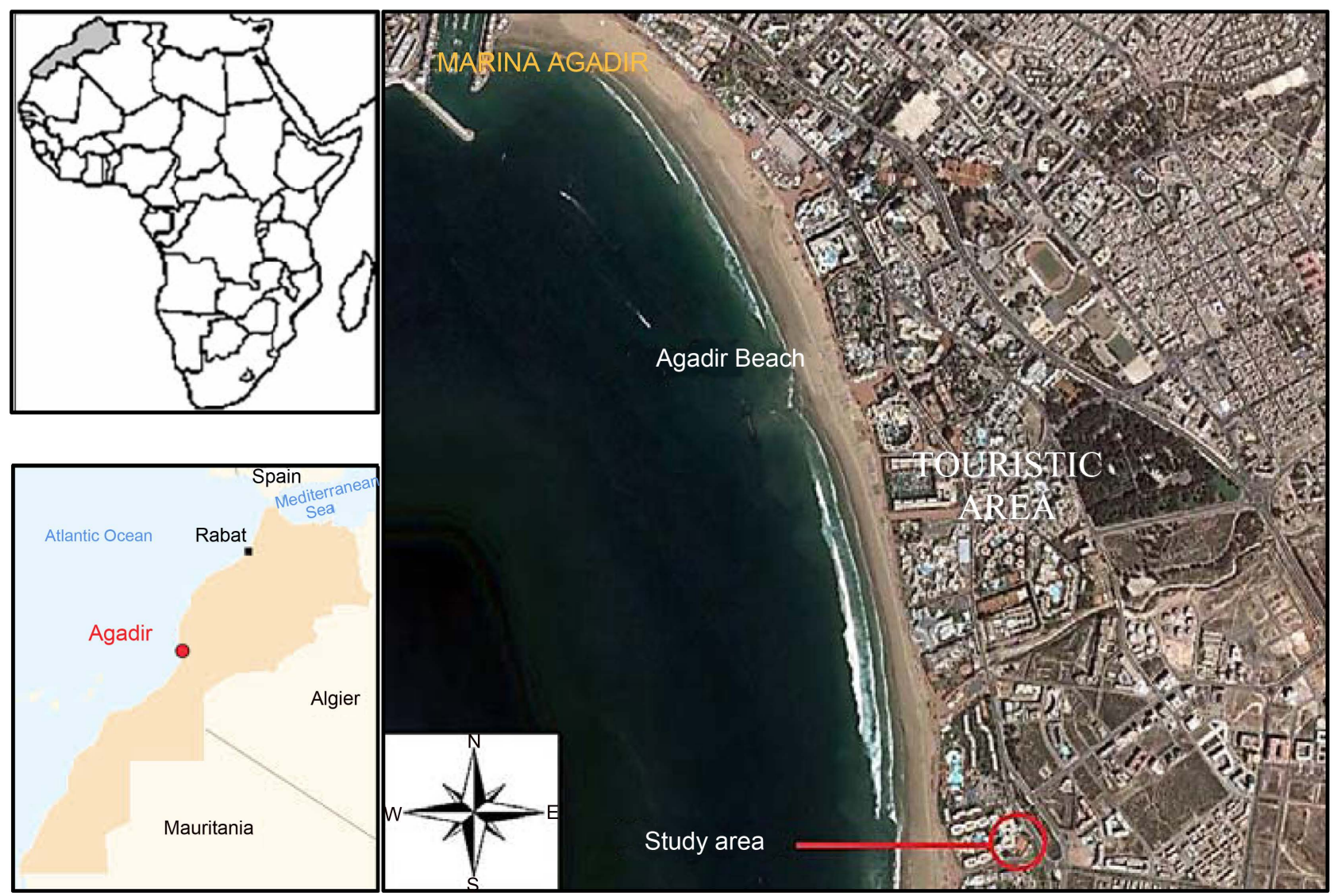

Figure 1. Agadir city location and water scale sampling sites in the city.

\section{Results and Discussion}

\subsection{X-Ray Fluorescence Analysis}

The qualitative analysis by X-ray fluorescence (XRF) was used to identify the chemical elements in the scale samples. Figure 2 shows the spectrums of major elements found in the hot water scale samples. According to the Figure 2(b), the calcium is the major element. It presents an intense peak at the wavelength $0.336 \mathrm{~nm}$. It is followed by the Iron at $0.193 \mathrm{~nm}$ (Figure 2(a)), the Silicon at $0.713 \mathrm{~nm}$ (Figure 2(c)). Others elements such as Strontium, Sulfur, Chromium, Magnesium, Oxygen are also present with peaks of low intensities, and trace amount of other elements such as Nickel, Zinc, Phosphorus, Titanium, Manganese, Sodium, and Potassium.

$\mathrm{XRF}$ quantitative analysis results are presented in Table 1 . They show that the scale consists mostly of calcium carbonate with a content which reached $92.98 \%$. In addition, it was also observed that the loss on ignition for scale was found to be $44.33 \%$. This high value of loss is caused mainly by decomposition of calcium carbonate with formation of calcium oxide $(\mathrm{CaO})$ and carbon dioxide $\left(\mathrm{CO}_{2}\right)$ according to the reaction [3]:

$$
\mathrm{CaCO}_{3}(\mathrm{~s}) \rightarrow \mathrm{CaO}(\mathrm{s})+\mathrm{CO}_{2}(\mathrm{~g})
$$

The calcium oxide $(\mathrm{CaO})$ is the major oxide in scale samples. It represents $52.07 \mathrm{wt} \%$. Other oxides are also detected with very low contents. The silica $\left(\mathrm{SiO}_{2}\right)$ and magnesium 

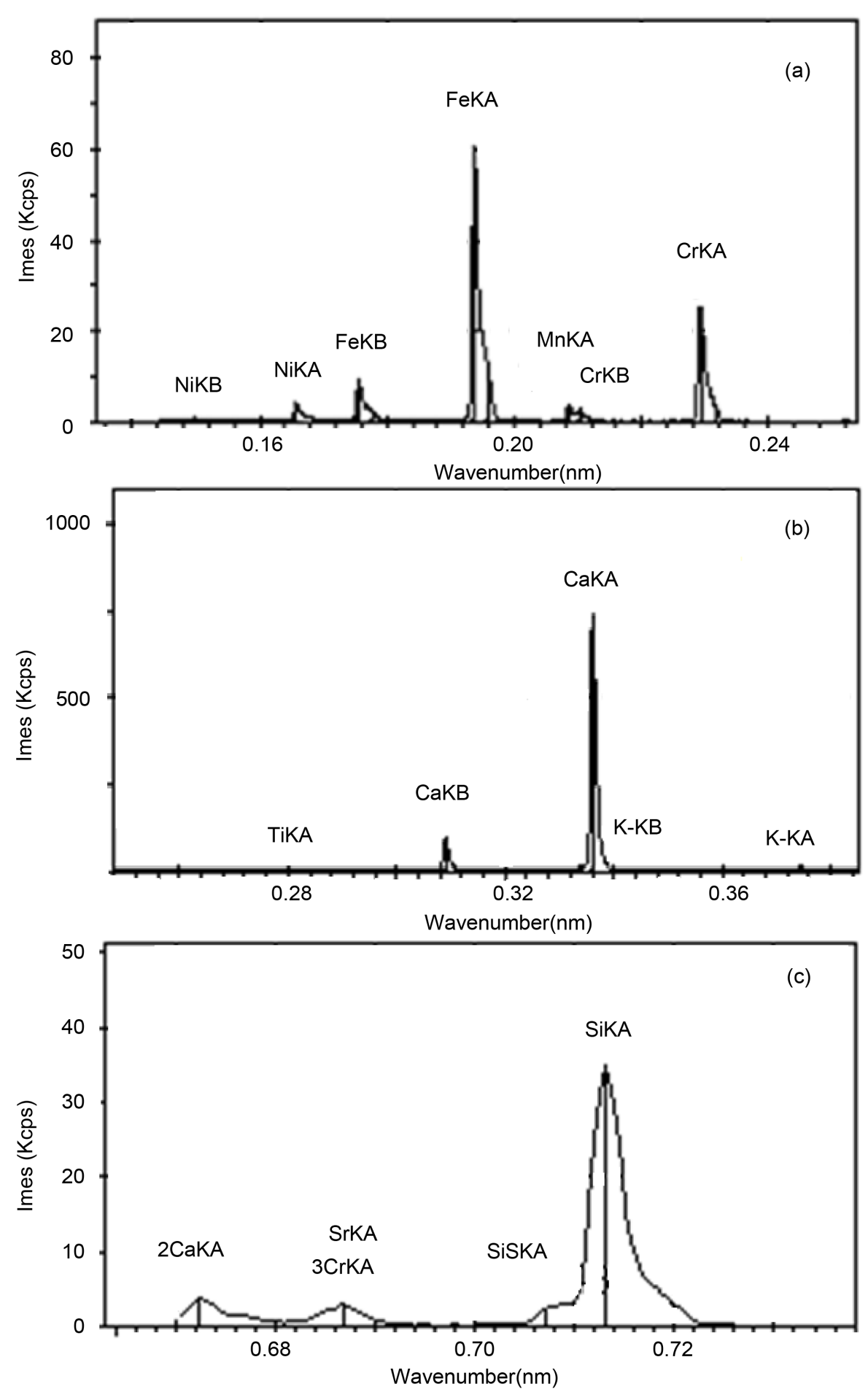

Figure 2. XRF spectrums of scale deposited in the hot water system.

oxide $(\mathrm{MgO})$ present respectively a percentage of $1.10 \%$ and $0.94 \%$ in weight. Other oxides in state of traces have been detected like sulphuric oxide $\mathrm{SO}_{3}(0.32 \%)$, phosphorus pentoxide $\mathrm{P}_{2} \mathrm{O}_{5}(0.22 \%)$, sodium oxide $\mathrm{Na}_{2} \mathrm{O}(0.20 \%)$, iron oxide $\mathrm{Fe}_{2} \mathrm{O}_{3}(0.11 \%)$, aluminium oxide $\left(\mathrm{Al}_{2} \mathrm{O}_{3}\right)(0.09 \%)$. 


\subsection{Elementary Analysis CHNS/0}

The Elemental chemical Analysis CHNS/O has been conducted to determine the percentage of the mass of Carbon, Hydrogen, Nitrogen, Sulphur or Oxygen in the scale samples. Table 2 summarizes the analytical results obtained. It shows that the scale studied contains $49.68 \%$ of oxygen and $10.70 \%$ of carbon. These values correspond to mass proportions of oxygen (48\%) and carbon (12\%) in calcium carbonate molecules.

The hydrogen and sulphur elements are present with very low percentages which are respectively $0.35 \%$ and $0.17 \%$. The nitrogen element has not been detected as seen at Table 2.

\subsection{Infra-Red Analysis}

The analysis by IR spectroscope has given the results presented in Figure 3. The spectrum has allowed to identify the absorption bands corresponding to the different vibration characteristics bonds in the scale sample. This spectrum shows characteristics bands of the $\mathrm{CO}_{3}^{2-}$ : bands at $700.36 \mathrm{~cm}^{-1}, 713.30 \mathrm{~cm}^{-1}, 854.68 \mathrm{~cm}^{-1}, 1082.90 \mathrm{~cm}^{-1}$ and at $1479.01 \mathrm{~cm}^{-1}$ [4] [5]. In addition, the band near $1789 \mathrm{~cm}^{-1}$ pointed to the presence of carboxyl $\left(\mathrm{COO}^{-}\right)$, which came from $\mathrm{CO}_{3}^{2-}$ and the surface adsorption of ambient water [5]. The spectrum of the aragonite is characterized by a double peak at 700 and 713 $\mathrm{cm}^{-1}$ [6]. Compared to calcite, aragonite is less stable under ambient thermodynamic conditions. It has an orthorhombic crystal structure. Experimental parameters of structure found by Dickens and Bowen $\mathrm{a}=4.9598 \AA$, $\mathrm{b}=7.9641 \AA$, and $\mathrm{c}=5.7379 \AA$ [ [7] [8].

\subsection{Thermal Analysis}

The thermal decomposition of sample is shown in Figure 4. DTA curve shows endothermic peaks in the region of 0 to $300^{\circ} \mathrm{C}$ associated to the elimination of the surface

Table 1. Chemical composition of the scale samples in hot water system.

\begin{tabular}{cc}
\hline Compound & Weight \% \\
\hline Calcium oxide $(\mathrm{CaO})$ & 52.07 \\
Silica $\left(\mathrm{SiO}_{2}\right)$ & 1.10 \\
Magnesium oxide $(\mathrm{MgO})$ & 0.94 \\
Sulphuric oxide $\left(\mathrm{SO}_{3}\right)$ & 0.32 \\
Phosphorus pentoxide $\left(\mathrm{P}_{2} \mathrm{O}_{5}\right)$ & 0.22 \\
Sodium oxide $\left(\mathrm{Na}_{2} \mathrm{O}\right)$ & 0.20 \\
Iron Oxyde $\left(\mathrm{Fe}_{2} \mathrm{O}_{3}\right)$ & 0.11 \\
Aluminumoxide $\left(\mathrm{Al}_{2} \mathrm{O}_{3}\right)$ & 0.09 \\
Potassium Oxide $\left(\mathrm{K}_{2} \mathrm{O}\right)$ & 0.00 \\
\hline
\end{tabular}

Table 2. Results of the elementary analysis CHNS-O of scale deposited.

\begin{tabular}{cccccc}
\hline Element & $\mathrm{C}$ & $\mathrm{H}$ & $\mathrm{N}$ & $\mathrm{S}$ & $\mathrm{O}$ \\
\hline Weight $\%$ & 10.70 & 0.35 & 0.00 & 0.17 & 49.68 \\
\hline
\end{tabular}




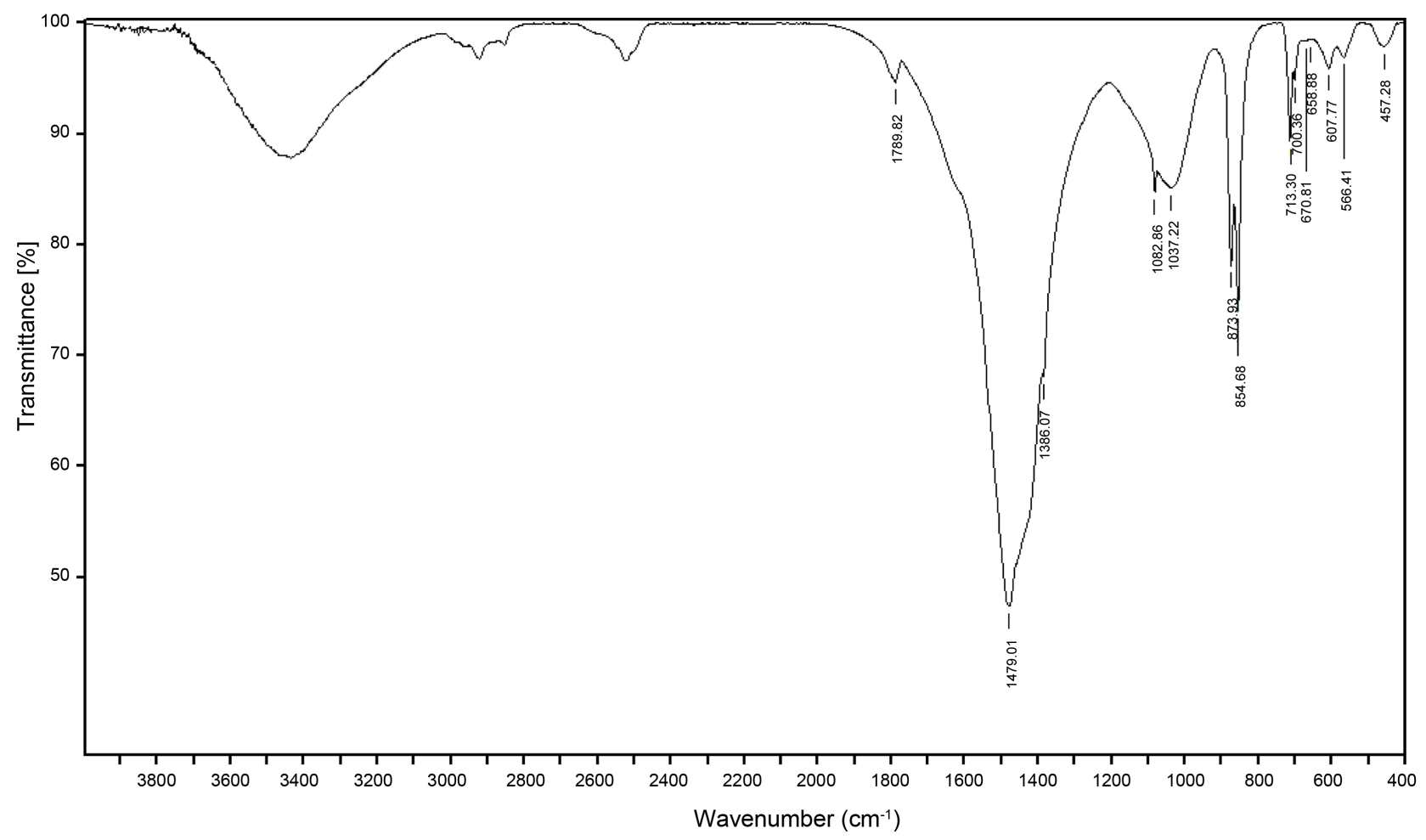

Figure 3. Infrared spectrum of scale formed in hot water system.

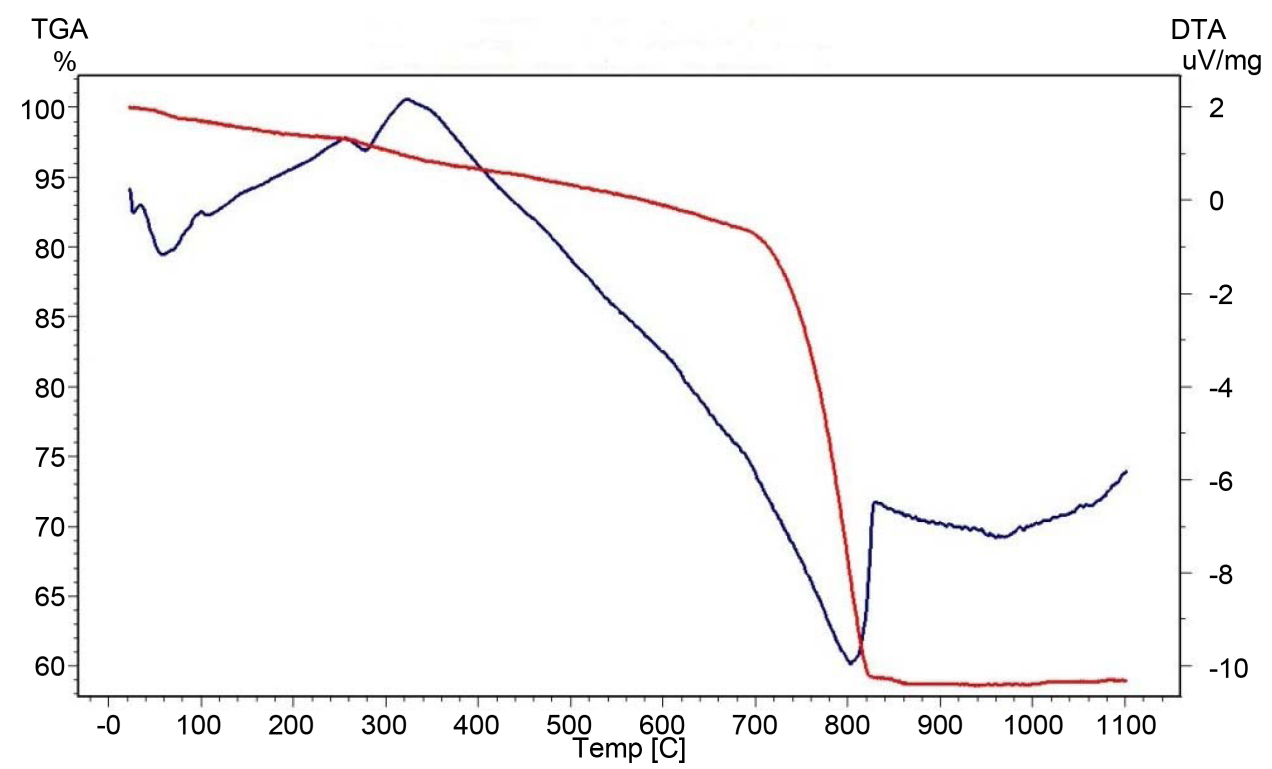

Figure 4. Thermogravimetric and differential thermal analysis curves of scale hot water.

and lattice water. Whereas, the endothermic peak at $800^{\circ} \mathrm{C}$ is attributed to the decomposition of calcium carbonate $\mathrm{CaCO}_{3}$ to $\mathrm{CaO}$ and $\mathrm{CO}_{2}$. TGA analysis curve show a total mass loss of 41\%:8\% loss of surface and lattice water between $0^{\circ} \mathrm{C}$ to $300^{\circ} \mathrm{C}$ and $33 \%$ at high temperature associated to the elimination of vapors such as $\mathrm{CO}_{2}$ generated by the decomposition of calcium carbonate. These observations are in agreement with the 
literature data $\left(39 \%\right.$ to $43 \%$ for a temperature between $500^{\circ} \mathrm{C}$ and $700^{\circ} \mathrm{C}$ and the $44 \%$ as theoretical value) [5] [9].

\subsection{X-Ray Diffraction Analysis}

Figure 5 presents the XR diffractogram of studied scale. It also shows that the scale essentially consists of aragonite $\mathrm{CaCO}_{3}$ (JCPDS card No. 00-005-0453), with a presence of the Mg-calcite $\mathrm{Mg}_{0.06} \mathrm{Ca}_{0.94}\left(\mathrm{CO}_{3}\right)$ (JCPDS card No.01-089-1306) which corresponds to the peak $2 \theta=29.7033^{\circ}[10]$.

The peaks which include $2 \theta=27.5^{\circ}, 33.5^{\circ}$ and $45.9^{\circ}$ correspond to the calcium carbonates of the aragonite type which is metastable to the ordinary temperature and which is formed at a temperature above $60^{\circ} \mathrm{C}$ [11] [12] [13] [14]. With the exception of the peaks at $2 \theta=29.7^{\circ}, 39.79^{\circ}$ and $43.57^{\circ}$, all the peaks in the spectrum correspond to the aragonite variety of calcium carbonate [15] [16]. According to Wray J.L and Danniel F., the pure crystals of aragonite are obtained at $70^{\circ} \mathrm{C}$, by precipitation of the soluble calcium salts and carbonate [17]. Indeed, the high temperature in the piping of the hot water favours the formation of aragonite [16].

\subsection{Scanning Electron Microscopy Analysis (SEM)}

The scale samples analysis with the scanning electron microscopy (SEM) has given results as we can see at Figure 6. Micrographs obtained show that the scale structure is in the form of needles which confirms that it is composed of Calcium Carbonate $\mathrm{CaCO}_{3}$, type aragonite [14] [18].

\section{Conclusions}

The use of various analytical techniques has allowed us to identify and characterize the solid deposits found in the internal walls of hot water pipes in the south of the touristic area of the Agadir city.

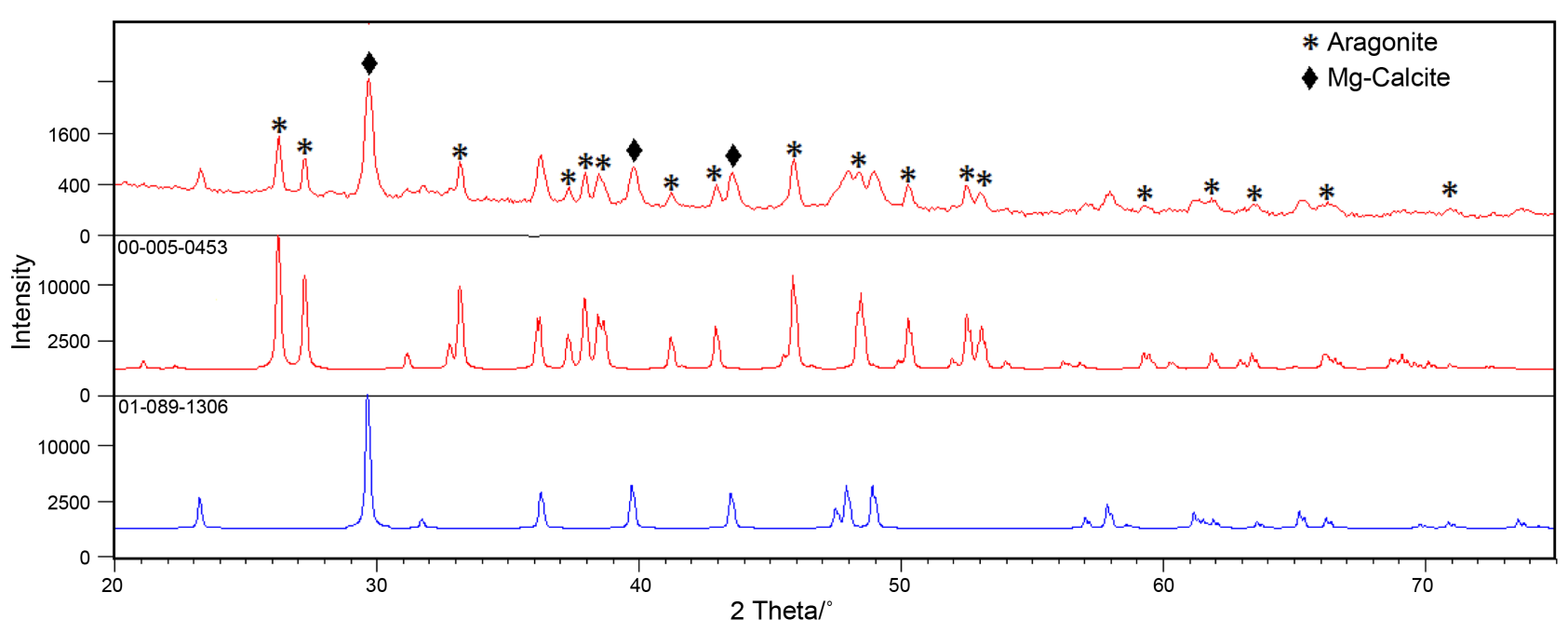

Figure 5. X-ray diffraction spectrum of hot water scale. 

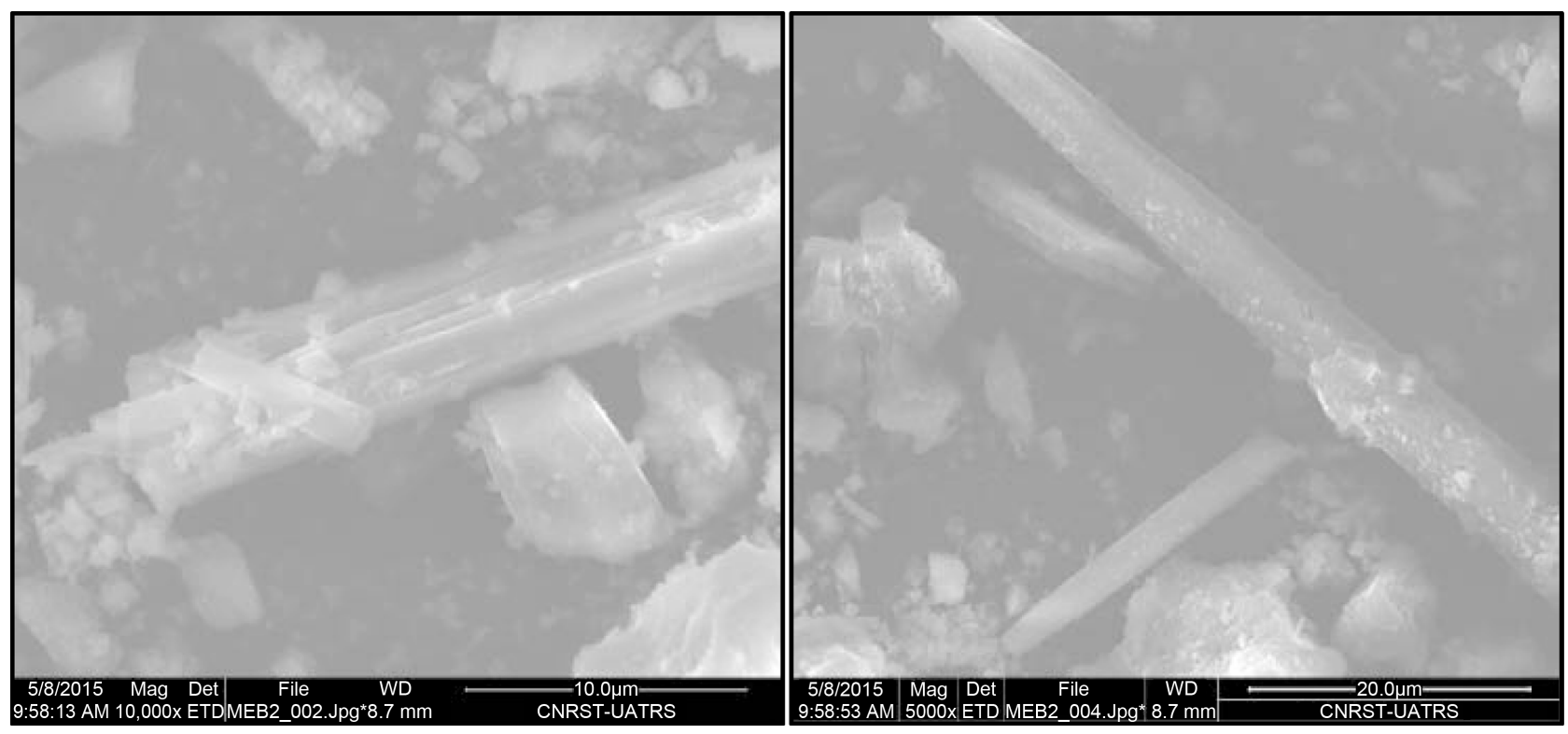

Figure 6. MEB micrographs of scale deposited in hot water system.

Quantitative analysis results showed that calcium carbonates amount exceeds 93 $w t \%$. The carbonates anion has been well identified in the infra-red spectrum. The process of decomposition of calcium carbonates has been highlighted by the quantitative analysis by XRF. The calcium oxide $\mathrm{CaO}$ represents $52 \%$ of the scale weight. Thermal analysis results confirmed this result and showed the calcium carbonate decomposition process. The crystal structure of the scale is the aragonite variety as it has been determined by X-ray diffraction. Micrographs obtained by scanning electronic microscope confirm this structure.

Indeed, the scale deposited in the hot water system is mostly formed of calcium carbonate. Due to temperature, particles of calcium carbonate were crystallized under the aragonite variety. These results will allow us to focus our research of suitable inhibitors of scaling in order to prevent the deposit of scale in the hot water system in the touristic area in Agadir city.

\section{References}

[1] The Regional Council Souss Massa Draa (2013) State of Places Agadir souss Massa Draa. Regional Center of Tourism.

[2] Agadir, R. (2014) Official Accounts, Management Report, Sector Drinking Water, 14-28.

[3] Junjun, Y., Kang, X., Changlei, Q., Feng, F., Ananthanarayanan, V. and Saulov, D. (2014) Modeling of $\mathrm{CaCO}_{3}$ Decomposition under $\mathrm{CO}_{2} / \mathrm{H}_{2} \mathrm{O}$ Atmosphere in Calcium Looping Processes. Fuel Processing Technology, 125, 125-138. http://dx.doi.org/10.1016/j.fuproc.2014.03.036

[4] Ben, X. and Kristin Poduska, M. (2014) Linking Crystal Structure with Temperature-Sensitive Vibrational Modes in Calcium Carbonate Minerals. Physical Chemistry Chemical Physics, 16, 17634-17639. http://dx.doi.org/10.1039/C4CP01772B

[5] Hongxia, G. Zhenping, Q., Qian P., Peng, Y., Suping, C. and Wei, W. (2011) Crystallization 
of Aragonite $\mathrm{CaCO}_{3}$ with Complex Structures. Advanced Powder Technology, 22, 777-783. http://dx.doi.org/10.1016/j.apt.2010.11.004

[6] Vagenas, N.V., Gatsouli, A. and Kontoyannis, C.G. (2003) Quantitative Analysis of Synthetic Calcium Carbonate Polymorphs Using FT-IR Spectroscopy. Talanta, 59, 831-836. http://dx.doi.org/10.1016/S0039-9140(02)00638-0

[7] Villiers, J.P.R.D. (1971) Crystal Structures of Aragonite, Strontianite, and Witherite. American Mineralogist, 56, 758-767.

[8] Nora, H., Leeuw, D. and Stephen, C.P. (1998) Surface Structure and Morphology of Calcium Carbonate Polymorphs Calcite, Aragonite, and Vaterite: An Atomistic Approach. The Journal of Physical Chemistry B, 102, 2914-2922. http://dx.doi.org/10.1021/jp973210f

[9] Shu-Chen, H., Kensuke, N. and Yoshiki, C. (2007) A Carbonate Controlled-Addition Method for Amorphous Calcium Carbonate Spheres Stabilized by Poly(acrylic acid)s. Langmuir, 23, 12086-12095. http://dx.doi.org/10.1021/la701972n

[10] Titschack, J., Goetz-Neunhoeffer, F. and Neubauer, J. (2011) Magnesium Quantification in Calcites [ $\left.(\mathrm{Ca}, \mathrm{Mg}) \mathrm{CO}_{3}\right]$ by Rietveld-Based XRD Analysis: Revisiting a Well-Established Method. American Mineralogist, 96, 1028-1038. http://dx.doi.org/10.2138/am.2011.3665

[11] Nakamura, A., Almeida, A.C., Espinoza, H., Araújo, J.L.F., Gouveia, V.J.P., Carvalho, M.D. and Cardoso, A.V. (2014) Polymorphism of $\mathrm{CaCO}_{3}$ and Microstructure of the Shell of a Brazilian Invasive Mollusc (Limnoperna fortunei). Materials Research, 17, 15-22. http://dx.doi.org/10.1590/S1516-14392014005000044

[12] Kontoyannis, C.G. and Vagenas, N.V. (2000) Calcium Carbonate Phase Analysis Using XRD and FT-Raman Spectroscopy. Analyst, 125, 251-255. http://dx.doi.org/10.1039/a908609i

[13] Rosset, R., Douville, S., Ben Amor, M. and Walha, K. (1999) The Inhibition of the Scaling by the Geothermal Waters of the South-Tunisian. Journal of Water Science, 12, 753-764.

[14] Knez, S. and Pohar, C. (2005) The Magnetic Field Influence on the Polymorph Composition of $\mathrm{CaCO}_{3}$ Precipitated from Carbonized Aqueous Solutions. Journal of Colloid and Interface Science, 281, 377-388. http://dx.doi.org/10.1016/j.jcis.2004.08.099

[15] Cuneyttas, A. (2015) Aragonite Coating Solutions (ACS) Based on Artificial Seawater. Applied Surface Science, 330, 262-269. http://dx.doi.org/10.1016/j.apsusc.2014.12.195

[16] Azizur Rahman, M., Halfar, J. and Shinjo, R. (2013) X-Ray Diffraction Is a Promising Tool to Characterize Coral Skeletons. Materials Physics and Chemistry, 3, 120-125. http://dx.doi.org/10.4236/ampc.2013.31A015

[17] Wray, J.L. and Danniels, F. (1957) Precipitation of Calcite and Aragonite. Journal of the American Chemical Society, 79, 2031-2034. http://dx.doi.org/10.1021/ja01566a001

[18] Wang, L.F., Sondi, I. and Matijevic, E. (1999) Preparation of Uniform Needle-Like Aragonite Particles by Homogeneous Precipitation. Journal of Colloid Interface Science, 218, 545-553. http://dx.doi.org/10.1006/jcis.1999.6463 
Submit or recommend next manuscript to SCIRP and we will provide best service for you:

Accepting pre-submission inquiries through Email, Facebook, LinkedIn, Twitter, etc. A wide selection of journals (inclusive of 9 subjects, more than 200 journals)

Providing 24-hour high-quality service

User-friendly online submission system

Fair and swift peer-review system

Efficient typesetting and proofreading procedure

Display of the result of downloads and visits, as well as the number of cited articles

Maximum dissemination of your research work

Submit your manuscript at: http://papersubmission.scirp.org/

Or contact jwarp@scirp.org 